Article

\title{
Social Sustainability and Transformation in Higher Educational Settings: A Utopia or Possibility?
}

\author{
Lili-Ann Wolff ${ }^{1, *(1)}$ and Peter Ehrström ${ }^{2}$ \\ 1 Faculty of Educational Sciences, University of Helsinki, PB 9, 00014 Helsinki, Finland \\ 2 Regional Science, Faculty of Education and Welfare Studies, Åbo Akademi University, PB 311, \\ 65101 Vaasa, Finland; peter.ehrstrom@abo.fi \\ * Correspondence: lili-ann.wolff@helsinki.fi; Tel.: +358-50-4487088
}

Received: 24 March 2020; Accepted: 18 May 2020; Published: 20 May 2020

check for updates

\begin{abstract}
Social sustainability is a dimension of sustainability that has received little attention. Our aims in this article are to create a definition of social sustainability based on a comprehensive literature study, and to discuss the implementation of the concept in higher education settings at theoretical and practical levels. We also aim to answer the question of whether it is possible to achieve a socially sustainable and transformative practice in educational contexts. Our approach in the study is critical and reflective and, firstly, built on a literature review including policy documents, research articles and books on sustainability from the perspectives of education and social studies. Secondly, we provide examples of practice from four university sustainability courses. In these courses, social sustainability appears in an interdisciplinary and a sustainable leadership framework. The conclusion from this study is that it is possible to implement social sustainability in various ways at the course level. We identify elementary features at basic, personal and educational levels that facilitate the implementation. However, we see the inclusion of social sustainability as the only way to reshape education and rethink the role of educational institutions. In this reshaping, ethics is the core.
\end{abstract}

Keywords: social sustainability; sustainability education; social sustainability learning; transformative learning; interdisciplinarity; transdisciplinarity; sustainable leadership; higher education

\section{Introduction}

Since the 1990s, there has been increased international attention on sustainable development and sustainability issues. According to UNESCO (United Nations Educational, Scientific and Cultural Organization), the difference between the two concepts is that sustainability is a long-term goal towards a more sustainable world, whereas sustainable development implies the processes to reach this goal [1]. The visionary concept sustainability started emerging from multiple sources in the 1960s [2], while the word combination sustainable development was introduced 1980 in the World Conservation Strategy [3] and declared to be a political agenda in the Brundtland Report in 1987 [4]. Education is thus one of many components in the sustainable development process or the route towards a more sustainable society [1]. Since the concepts sustainability and sustainable development are not clearly distinct, it is not always easy to separate them.

The three dimensions of sustainable development (also referred to as pillars) are well known and termed the ecological (also called environmental), the social (also split into social/cultural) and the economic dimensions. Even if the social dimension has been distinct, ever since sustainable development emerged in politics, this dimension has been more or less neglected as wider debates in general have prioritized environmental (i.e., climate change) and economic (i.e., industrial capitalism) perspectives [5]. The key question that Davidson always finds present when it is necessary to define 
the social dimension is "What type of society do we want to sustain?" [5] (p. 616). In this question, he sees an underlying political potential with an urgent call for social ethics. Ten years on, this can still be regarded as the core question related to a wider understanding of sustainability in general, and social sustainability in particular. To this question, the following could be added: Who wants to sustain their society, whose is the society and for whom is it to be sustained?

Many of the contemporary sustainability challenges relate to the social sphere. Risks and vulnerability arise from social polarization, urban poverty, conflict, terrorism, and natural disasters [6]. Moreover, climate change and its effects have a strong connection to social life. All these challenges prompt a rethinking of planning and a reflective choice of methods.

Many researchers argue that the Earth has reached a new geological epoch, which they call the Anthropocene [7]. With this new epoch, they emphasise the strong human-influenced (anthropogenic) changes in the Earth's physical features, causing huge changes in the Earth's systems, with impacts far beyond the physical sphere. Simultaneously, as this irreversible situation requires a stronger ecological perspective on life on Earth, there is a need for human cooperation, democracy, and social justice [8]. That there is a place for social sustainability is thus obvious. According to UNDESA (United Nations Department of Economic and Social Affairs) The World Social Report 2020 [9], governments can tackle technology change, migration, urbanization and climate crises cleverly, or leave them to divide the world population even more, since these trends easily produce a division between winners and losers; "applying an equality lens means redoubling efforts to address the root causes in equality now" [9] (p. 13). Multilateral institutions and governments need to be fully committed to take action and reduce global inequality.

In 2015, the United Nations member states adopted the 2030 Agenda for Sustainable Development (called Agenda 2030) and the Sustainable Development Goals (SDGs) to steer the promotion of sustainable development from 2016 to 2030. Agenda 2030 and its 17 Sustainable Development Goals and 169 targets strive towards urgent action on climate change, and stress that humans need to live in harmony with nature and protect other species [10]. The agenda is 'a plan of action for people, planet and prosperity,' (p. 3) and it sets out an integration of ecological, economic and social objectives; meanwhile, it strongly addresses the social dimension of sustainability. The aim of the goals and targets is to foster peaceful and inclusive societies: by underscoring human rights, dignity and equality; by an intention to end poverty and hunger; and by underscoring the empowerment of women and girls and the most vulnerable people in the world. A core promise is 'to leave no one behind,' and, specifically, goal 10 focuses on reducing inequality within and between countries.

For the first time in history, there is an internationally agreed development goal to reduce economic inequality [9]. However, there are still deep divides between and within countries [9], and much needs to be done. International cooperation is essential, and governments are the key players. Education also has an urgent role to play, but education does not necessarily lead to a more sustainable world. The education systems may even reinforce inequality based on socioeconomic status, race and ethnicity [9].

Goal 4 of the 17 Sustainable Development Goals particularly focuses on the equal right for all to receive an education: Ensure inclusive and equitable quality education and promote lifelong learning opportunities for all. Sub goal 4.7 states:

“By 2030, ensure that all learners acquire the knowledge and skills needed to promote sustainable development, including, among others, through education for sustainable development and sustainable lifestyles, human rights, gender equality, promotion of a culture of peace and non-violence, global citizenship and appreciation of cultural diversity and of culture's contribution to sustainable development" [10] (p. 19).

Nevertheless, there are now obvious deficiencies in the implementation of sustainability in education, not least in university education [11-13]. Courses in sustainability are mainly focused on specific subjects and special areas. Sustainability and sustainable development are complex concepts 
that also require interdisciplinary understanding [14]. Therefore, the social view must be included in education at all levels.

\section{The Social Dimension of Sustainability}

Even if the social dimension of sustainability has been investigated and interpreted less often than the ecological (environmental) and economic dimensions [6,15-17], there have been increased efforts to implement the social dimension in various fields [18]. Such fields include urban planning, management, leadership and business. Dillard et al. noted that the tripartite understanding of sustainability has sometimes been referred to as the three Es: environment, economy, and equity in urban planning, but that "social sustainability is conceived of as equity, without considering what that might require or whether equity alone is sufficient for social sustainability" [15] (p. 3).

Nonetheless, Roos [19] (p. 123) argues that there will still be much to do until ethics, social responsibility and sustainability have convincingly been implemented into business schools, and until it has become a deep wisdom in the 'hearts and minds' of the students. Profit is still a basic aim that directs sustainability thinking. If social sustainability is only interpreted as an outward element or a vision, it will not become a reality.

\subsection{The Interpretation of Social Sustainability}

Social sustainability is a vague concept $[16,20]$, and it is the dimension that is most difficult to define. Diverse disciplines have distinct definitions $[17,20]$. One explanation for this is that nature and environmental issues often link to different ontologies and epistemologies, and the ecological and social dimensions may even be in conflict [18]. Consequently, studies about the material world are based on a positivistic approach and explored quantitatively, while the social world is based on a constructivist or critical approach and is explored qualitatively.

The multitude of ways to understand and interpret the concept may be an explanation of why it is so difficult to combine social sustainability purposefully with the other two dimensions of sustainability. Magis and Shinn stress that social sustainability has to be understood as being distinct from the ecological and economic sustainability dimensions [21]. This means that, on one hand, social sustainability is distinct, and on the other, it has to be grasped as a part of the whole sustainability dilemma. A problem in education is that social sustainability is so strongly value-laden, and value-laden issues have always been a challenge in education [22].

Sustainability strategies both need analytic depth and clearly defined expected social values [17]. The central elements of social sustainability are human wellbeing, equity, democratic governments and democratic civil society [21]. In addition to these are elements like cultural diversity, gender issues, individual capabilities, and quality of life [18]. Bailly et al. emphasise that urban research and policy development need to devote more attention to links between social and spatial considerations, "as they are the main components of the complexity underlying the integrated management of cities" [23] (p. 131).

The development of the world is also a core element in the sustainable development debate. However, there is a growing emphasis on the goal of development needing to be rearticulated and development processes being reconstructed, governance being revalidated and democratized, and the need for indicators of success to be redefined [21]. This means that the prevailing social norms are no longer relevant. In a sustainable society, the social visions and goals have to be in line with sustainability aims and not with neoliberal ideals. This reinforces the claim that society must change, so that sustainable visions are based on reality. In this change process, education plays a crucial role, but the most crucial element is politics.

Politics directs both the economy and education and is the context in which reforms have to start to lead societies towards social sustainability on a global scale. In the Anthropocene, societies need to build social resilience to the environmental challenges and risks and raise awareness about global threats at a local level [24]. A cornerstone is to connect people, so they can solve problems collectively. 
A socially sustainable society is one that is just, equal, and in which no one is excluded. In addition, it is a society that allows all citizens to live a decent life in freedom [16]. It is also a society in which people are not subjected to any structural obstacles to health, influence, competence, impartiality or meaning making [25]. Critics can consider these ideals to be naïve or unrealistic, in a strongly unequal world, but it is important to list and argue for them as universal ideals worth striving for. Simultaneously, these ideals have to be taken seriously, and handled in politics to lead to change practices. Social sustainability is both a means and a need, according to Konig, and it is often associated with Bourdieu's concept of social capital as well as cultural capital $[16,26]$. Social capital is based on kinships, friendships, and personal connections (groups, social practices), and institutions (e.g., educational institutions). Membership in a group is an advantage because of the reciprocal exchanges between members of the group [27].

According to Bourdieu, cultural capital is the long-lasting accumulation of knowledge, behaviours, and skills by which people demonstrate their cultural competence and social status [27]. A person's cultural capital is dependent on education, socialization and belongings (e.g., books, cloths, electronic devices), but institutions also support the development of cultural capital through measurements and ranking systems, etc. These capital theories refer to structures of dominance and symbolic power that are hidden in social institutions and systems [28], and which thus slow down purposeful equality processes. Larsen emphasizes that social sustainability cannot be excluded from the ecological and economic perspectives [29]. He stresses that social sustainability has to

"(a) build inclusion at the level of the individual, groups and society; (b) provide for basic human dignity, which includes at least basic human sustenance, freedom from tyranny, freedom of association, and basic human liberty; (c) provide a means for people to influence their governance; and (d) create the capacity for learning at the level of individuals, groups, collectives, governments, corporations, and society". [29] (p. 78)

Like many others, Littig and Grießler have tried to create indicators to measure social sustainability [17]. Firstly, the indicators of social sustainability have to do with basic human needs and quality of life, and relate to individual income, poverty, income distribution, unemployment, education and further training, housing conditions, and health. Secondly, there are indicators relating to social justice and equal opportunity, and the third set of indicators connect to social coherence, and include integration in networks, involvement in social activities, tolerant attitudes, etc. However, social sustainability is not something one creates ad hoc. It demands a large reconstruction of society. Equity is based on the redistribution of wealth, which, in turn, is based on the reconstruction of power constellations in order to enable the elimination of social, economic and legal barriers that create social and economic hierarchies and thus marginalization [21]. A democratic society builds on empowerment and political and civil freedom [21]. A right for all to education, including sustainability education, is a part of this freedom. Sustainability education is not only value laden, it is also very context dependent, because of the character of all the sustainability dimensions.

\subsection{The (In)distinct Character of Social Sustainability}

Social sustainability's indefinite connection to the other sustainability dimensions is a problem that makes it an unclear educational topic. There is no consensus on the hierarchy between the three dimensions of sustainability [17]. Therefore, social sustainability may be one of three equally important dimensions, or the most basic dimension, or a basis for the economic dimension, or something else. It is also unclear if the social dimension is analytic or normative [17].

The social dimension of sustainability includes both procedural aspects, which means how to reach the goals, and substantive aspects-that is, what to do [18]. However, these aspects are intertwined and relate to the other sustainability dimensions. The ecological dimension is often the foundation upon which the social and the economic are built [17]. Walsh suggests that the environmental dimension is the most important dimension in less developed countries [30]. To build his arguments, he employed Maslow's hierarchy of needs, grounded in psychology, combined with Porter's value chain theory, 
grounded in strategic management. Basic physical needs depend on vital ecosystems. Fresh water supply, clean air, physical health, shelter and food are the most crucial elements, and these come before higher order human needs. For this reason, investments also must address social and economic circumstances with ecological sustainability as the basic aim. However, the hierarchy levels are mixed since, for example, water supply is connected to power constellations and equal rights and is therefore a political distribution problem. The social and the ecological dimensions interact, so improvements in one dimension trigger improvements in the other. For example, an ecologically sustainable society leads to less working hours, and more gender equality [17]. The opposite can also be a fact. Liberal politics have become the norm, even if they have caused unsustainable planetary and economic transformations that, in turn, have led to inequality both within and between nation states [8].

According to Konig, it is problematic that the concept of social sustainability is so ambiguous, and this in turn connects to the challenges of scope and scale [16]. It is difficult to find a common framework for local, regional and international levels, rural and urban contexts, not to mention northern and southern countries. This makes it a challenge to find indicators suitable for various situations and places. In poor countries, an implication of social sustainability is that individuals and families have the opportunity to a decent livelihood [16]. Then, human units need to cope with and adapt to stress, change, droughts, floods, indebtedness and decreased income. In rich countries, social sustainability is more about protecting the current social systems of social welfare and policy, and thus it easily is separated from the ecological dimension [18]. In addition, many factors do not function on local, regional and global levels anymore, since elements that are usually thought of as functioning on these three levels have become extremely complex and interrelated [31,32]. Even if the infrastructure and preparedness for catastrophes may be better in wealthier countries, the risks are similar everywhere. Floods, hurricanes and air pollution affect places in the world both predictably and unpredictably, independent of their economic level [33]. The effects of climate change are non-linear problems with many synergetic interactions, and an implicit unpredictability.

Dillard, Dujon and King distinguish between social sustainability as the processes that generate health and wellbeing and the social institutions that facilitate environmental and economic sustainability now and those that will do so in the future [15]. These processes are both a means and an end to social sustainability [15]. In addition, social sustainability needs to become a deep ethical element. Even if the human need for self-satisfaction is infinite, the Earth has a limit and so does acceptable distributive injustice. Therefore, sustainability ethics is an important topic in education [22].

\subsection{Acting Socially Sustainably}

According to Rieckmann, a task for education for sustainable development is to support individuals so they start to reflect on their own roles as actively promoting global social and environmental sustainability now and in the future [34]. When Roos discusses sustainability in business schools, he requests a more holistic education [19]. In addition to cognitive elements, Roos also refers to Aristotle's practical wisdom, phronesis, and calls for physical, emotional, and spiritual elements in learning situations. For students to learn to handle moral dilemmas, he not only recommends the use of less analytic and cognitive tools like drama and sports, but also recommends critical reflections and discussions. To hold practical wisdom and act sustainably in business means that one is able to balance constantly between collective and individual interests, between short-term and long-term goals, and to choose between being the one who adapts to or the one who shapes the environment [19].

According to Missimer et al., the crucial elements to be maintained in a socially sustainable context are trust, common meaning, and diversity [25]. These contexts need to create a capacity for learning and a capacity for self-organization. Even if these criteria are not especially conceived for educational settings, they are still applicable in these contexts. The social dimension of sustainability supports equality in culturally diverse learning situations. It deals with inequality and power issues [22], and should recognize challenges at ethical, cognitive and practical levels [13]. 
Not only do the students have to learn to act sustainably, but it is also something that all educational institutions have to do. Bourn writes about global learning and this issue has much in common with what could be called social sustainability education [35]. He asks for a whole-school approach and, similarly, Leal Filho et al. ask for a whole-university approach [36]. In such an approach, the global themes are incorporated as a part of the institutional ethos. It is not only a learning or teaching topic, but a way of relating to the world, involving activities from discussions to planning and practice. Accordingly, issues like fairness, tolerance and responsibilities become a part of the daily school (or university) life [36].

Universities must serve as sustainability models, initiating a transformation towards sustainable solutions [36,37]. A sustainability ethos is then present in the university's teaching, learning, research, campus operations and interactions with the rest of society. In a world in which sustainability has become a must, universities need to play a noticeable and leading role. The sustainable transformation of universities depends on the activities of both faculty members and students [36,37], and internal and external stakeholders [37], so the universities can make links to the real world [36]. Thus, sustainability becomes a new educational (Bildung) project and, at the same time, "a dynamic and flexible synergy issue for different sciences and subjects so that science, education, art, and practices are combined, transformed and developed" [37] (p. 62). In this project, academics' reflections on their own values are crucial [36].

It must also be considered that universities are dependent on politics and economics, at both national and international levels [13,37]. Therefore, university visions and strategies reflect many ideas and trends in society. Education policy often strives to make the students productive, and regard teachers as a factor in the production of learning [38]. The idea of education that develops ethical attitudes contradicts an instrumental view of knowledge and education that closely equates these with global commodities $[38,39]$. If economics is the guiding star, then the leaders are responsible for realizing what the economic forces are asking for.

For organizations and societies (also educational institutions) to succeed in becoming more sustainable, they need leaders that can provide a vision, set a direction, and motivate people [40]. When sustainable leadership is the rule, the links between organizations and society will be based on broad goals and ethical behaviour [41,42]. Sustainable leaders and organizations have social responsibilities outside their own context and need to engage their stakeholders in a joint sustainable change process [42].

\section{Social Sustainability Education and Learning}

In the UNESCO publication Issues and trends in education for sustainable development, Rieckmann argues that education for sustainable development must focus on more than sustainability-related content [34]. Its role is also to create interactive, learner-centred teaching and learning settings characterized by learning that is self-directed, participative, collaborative and problem-orientated [34]. The views of this pedagogy are both inter- and transdisciplinary. Rieckmann calls it an 'action-oriented transformative pedagogy' [34] (p. 56).

Sustainability calls for education that encourages a good human life, with well-functioning and decent communities adjusted to existing physical circumstances [22]. Education must make a difference and promote self-transformation and the transformation of the societies that the individuals and groups are a part of [39]. In addition to transformative learning, Seppelin and Törn-Laapio see potential in collaborative learning to generate responsibility in relation to sustainability. In the collaborative learning process, the students are free to participate in discourses and have various roles and equal opportunities [43]. The transformative learning process, again, calls for critical reflections on biases and assumptions and promotes a shifting of perspectives [34,43-45]. Seppelin and Törn-Laapio emphasize that sustainability learning at university level is about both content and processes [43], and there is often a quest for a broader perspective than simply a disciplinary focus [13]. In Sections 3.1 and 3.2 
(below), we will discuss the meaning of the concepts transformative learning and various forms of cross-disciplinarity further, especially interdisciplinarity, in relation to education and learning.

\subsection{Transformative Learning}

In discussions about sustainability, and especially in relation to teaching and learning, the topic of transformation is increasingly present, as already discussed. However, transformative learning is developed for use in adult education and based on deep theoretical understanding and cannot be applied anywhere and in any situation [46]. Since much is still unknown and unclear about transformative learning, Taylor warns against practising it naively without consideration or planning. He also stresses that learning, including transformative learning, is always context dependent, and it is therefore difficult to know how much the learning environment influences the outcome. Transformative learning may require intentional action, impersonal risks and genuine concern for the learners, in addition to the ability to use methods to create a learning environment that will support personal growth and social change. It is a demanding process, and it is therefore not obvious that every intention will succeed [47].

The aim of transformative learning is to lay the foundation for social actions. As a theory, it is a metacognitive epistemology, in which learning is a process to transform problematic mindsets, meaning changing the perspectives and habits of minds based on preconceptions to make them more open and able to change [44,45]. The transformation may be very sudden or progress slowly $[44,45]$.

Beside Mezirow's three core elements of individual experience, critical reflection, and dialogue, Taylor lists a holistic orientation, awareness of context, and an authentic practice with meaningful relationships as crucial in transformative learning [46]. These elements are not separate but are strongly interconnected. Sustainability is a value-laden concept that suits a transformative approach. Sustainability courses may offer opportunities for new alternative experiences in authentic situations and includes options for value related reflections and discussions based on theories as well as practice. Such courses trigger new ways of thinking and make the students see things in new perspectives. A holistic way of learning entails that both the intellect and the emotions are involved and that the methods are multimodal and thus various.

The educators are crucial in the learning process. Sustainability teaching and learning requires engaged and creative educators [48]. It is the educators' role to raise provocative questions and encourage critical thinking by asking for convincing arguments. The adult educators help the students to acquire the skills, sensitivities, and understanding so they become critically reflective participators in dialectical discourses [45]. The discussions between students are important: "It is within the arena of dialogue that experience and critical reflection playout," according to Taylor [46] (p. 9). The educators need to be aware of the learners' attitudes, feelings, personalities, and preferences, and be ready to respond to these when necessary. This means that transformative learning strongly depends on a trustful atmosphere $[46,48]$. Such an atmosphere is definitely also a precondition for sustainability learning.

\subsection{Broadening the Disciplinary Perspective}

Meeting sustainability challenges requires transdisciplinary approaches to understand better and take care of complex authentic problems and create practice-oriented learning situations, according to Biberhofer and Rammel [49]. According to Fox et al., resilience building and human adaptation to the Anthropocene will require a broad interdisciplinary understanding, bridging the present social and environmental challenges [24]. Only when the social spheres become a part of the natural Earth systems will it be possible to address the contemporary complex challenges of the Anthropocene $[24,50]$. This demands the mutual understanding of both social and natural perspectives.

The concepts multidisciplinary, interdisciplinary and transdisciplinary are often used interchangeably as synonyms. Nevertheless, the word cross-disciplinary occurs as a collective concept including the other three [51]. According to Klein, there is a clear distinction between the 
concepts [52]. When talking about multidisciplinary approaches, the disciplines are many, but they remain separate. Interdisciplinary, on the other hand, implies that the disciplines are integrated and that the perspectives are broader because of theoretical or methodological collaboration between scholars from several fields. If the disciplines are not merely mixed, but the aim is a transgression and also co-production of knowledge with stakeholders outside of academia, Klein calls the approach transdisciplinary. In transdisciplinary research and education, the outcome may be unpredictable, because the fusion of disciplines produces something extraordinary and unforeseen that is much more than a sum of their parts.

In a collaboration between disciplines, the participants need to balance disciplinary understanding and disciplinary identities, and interdisciplinary or transdisciplinary understanding and identities [53]. In interdisciplinary learning, Boix Mansilla describes two ways [54]. Education starts from the whole, by firstly shaping a comprehensive picture, and then looking at the parts (the separate disciplines). Secondly, it starts from the separate disciplines and concludes with the whole. Both ways end with a synthesis of the different views to shape deeper and more meaningful learning.

\section{Case Studies}

Below, we give examples on how we implemented sustainability in four university courses, three in Finland and one in Germany: two main courses and two courses inspired by one of the main courses (see Table 1). Our intentions are to initiate discussions rather than to deliver excellent examples. It is our opinion that university courses always can and need to be improved, so education becomes a steady development process, in which new theories and experiences are encountered and transformed.

Table 1. Four examples on sustainability courses.

\begin{tabular}{|c|c|c|c|c|c|}
\hline Case & Year & Course & University and Faculty & Department & Students \\
\hline 1 & $\begin{array}{l}2015 \\
2016 \\
2017 \\
2018\end{array}$ & $\begin{array}{c}\text { The Complexity of } \\
\text { Sustainable } \\
\text { Development }\end{array}$ & $\begin{array}{l}\text { Åbo Akademi University } \\
\text { Faculty of Education }\end{array}$ & $\begin{array}{l}\text { Rural Studies and } \\
\text { Demography } \\
\text { Adult Education }\end{array}$ & $\begin{array}{c}\text { Domestic and } \\
\text { international students } \\
\text { from various disciplines }\end{array}$ \\
\hline 2 & 2017 & $\begin{array}{l}\text { Leadership for } \\
\text { sustainable global } \\
\text { change }\end{array}$ & $\begin{array}{l}\text { University of Helsinki } \\
\text { Faculty of Behavioral } \\
\text { Sciences }\end{array}$ & $\begin{array}{l}\text { Department of } \\
\text { Education and } \\
\text { Adult Education }\end{array}$ & $\begin{array}{l}\text { Swedish and Finnish } \\
\text { speaking students of } \\
\text { education and adult } \\
\text { education }\end{array}$ \\
\hline 1a & 2019 & $\begin{array}{l}\text { The Complexity of } \\
\text { Sustainability }\end{array}$ & $\begin{array}{l}\text { University of Hamburg } \\
\text { Faculty of Education }\end{array}$ & $\begin{array}{l}\text { Department of } \\
\text { Lifelong Learning } \\
\text { and Vocational } \\
\text { Education }\end{array}$ & $\begin{array}{l}\text { Domestic (German) and } \\
\text { international students of } \\
\text { education and lifelong } \\
\text { learning }\end{array}$ \\
\hline $1 b$ & 2018 & $\begin{array}{l}\text { The Suomenlinna Pilot } \\
\text { Project }\end{array}$ & $\begin{array}{l}\text { University of Helsinki } \\
\text { Faculty of Educational } \\
\text { Sciences }\end{array}$ & $\begin{array}{l}\text { Department of } \\
\text { Teacher Education }\end{array}$ & $\begin{array}{l}\text { Swedish speaking } \\
\text { student teachers }\end{array}$ \\
\hline
\end{tabular}

The first main course case, The Complexity of Sustainable Development (Case 1), was implemented as an interdisciplinary master's course at Åbo Akademi University ( $\AA \mathrm{AU}$ ), and so far it has run for four years, 2015-18 (formally arranged by the Rural Studies and Demography and Adult Education departments, respectively). Subsequently, students have been able to undertake Course 1a (at the University of Hamburg) and Course $1 \mathrm{~b}$ (at the University of Helsinki). The second main course case, Leadership for Sustainable Global Change (Case 2), was a course in adult education at the University of Helsinki and was arranged by the Faculty of Behavioral Sciences (now called Faculty of Educational Sciences). This was a master's-level bilingual course included in the adult education programme and it took place in 2017.

By presenting these cases of sustainability education courses, we emphasize the importance and potential of interdisciplinary educational settings and show examples of how social sustainability could be implemented in education as part of a more complete view of sustainability. In addition, we want to shed light on the important social dimension of sustainability and enhance a wider discussion 
on the implication of this educational dimension. We discuss students' experiences of the courses based on their oral and written course evaluations, student essays, discussions with co-lecturers and the authors' own observations, the authors' notes and the authors' mutual discussions and reflections. However, the evaluation methods were not systematic and similar in all courses, and the results are not comparable.

\subsection{Case 1: The Complexity of Sustainable Development}

In 2014, the authors of this paper initiated the discussion about an interdisciplinary course at Åbo Akademi University ( $\AA \mathrm{AU}$ ) and brought together lecturers from several disciplines to discuss the idea. As a result, the course The Complexity of Sustainable Development was arranged four times between 2015 and 2018 and valued as a five-ECTS master's course. Author 2 was the course administrator during these years. The initiators and the other lecturers were all experts within their own fields of sustainability, but had similar aims and expertise connected to sustainability as the initiators. It was obvious from the beginning that the vision was an interdisciplinary course open to both domestic and international (exchange) students. Therefore, the course was taught in English.

In the first two years of the course, it was arranged within the frame of Rural Studies and Demography (later named Rural, Urban and Environmental Studies, RUM), which was one of the founding disciplines. For the third and fourth year, the Adult Education department took over responsibility for the course, and it was formally arranged as a course in Adult Education. This transition was smooth, as Author 2 (one of the initiators and administrator), simultaneously moved from RUM to Adult Education. However, the course was all four years a cooperation of several subjects at $\AA A$ U. In the first year, the freestanding MediaCity unit also participated in the course. The fourth course version was arranged as a smaller-scale course, only offered to participants in Vaasa, not (via video) in Turku. The number of course participants varied over the years.

The same group of lecturers, more or less, cooperated for four versions of the course. Special funding was only available for the first year; in the following years, the course was completed without extra funding. When the course is rearranged, which is currently planned for the academic years 2020-22, it will be as part of a master's studies module at $\AA A$, arranged by Regional Science and in cooperation with the master's study programme in Education and Learning, with Author 2 as the course administrator.

The first aim of the course was to distinguish between ways to define the strong politically emphasized concept of sustainability. Secondly, the aim was to offer a broad interdisciplinary and multicultural view of sustainability from the research fields of sociology, philosophy, pedagogy, science, history, geography, technology and political science, highlighting all pillars of sustainability, with an emphasis on social sustainability dimensions. The views moved between micro- and macro-perspectives in various contexts.

A second aim was that the students in this course should receive a complex picture of sustainability, so they could understand diverse environmental standpoints and be able to reflect on and discuss sustainability issues by means of a multidimensional consciousness. Firstly, they should become familiar with several ways to act based on sustainability requirements in various sectors and fields of activity, as well as in the role of active citizens. Secondly, they should know how to link issues of sustainability to various physical and social contexts. Finally, they should understand how various interest groups might diverge in their views of sustainability.

These targets and concepts were identical for the first four versions of the course and will also provide the guidelines for the upcoming course versions. The first version of the course was held in the 2015 spring semester, the second in 2016, the third in 2017 and the fourth in spring semester 2018. Due to a change in personnel and loss of the three driving course initiators (because of retirement, a move to another university, and an international guest professorship) course interruption occurred in 2018-19 and 2019-20, but a new course is currently planned for the 2020-21 academic year. On the first three occasions, the course was physically held at the $\AA A$ U campus in Vaasa, with video link 
participation from the ÅAU campus in Turku. Hereby the course administrators also cooperated with the Center for Lifelong Learning.

In 2016-17, the following lecture blocks were included in the course: Course introduction, Human relationship with nature: A foundation for sustainability, Towards more sustainable energy technology, Sustainable rural development, Social sustainability and gentrification, Education for sustainable development: Political rhetoric or reality?, Sustainable leadership ( 2017 replaced by Sustainability as your global challenge: Social innovations and social movements), Final seminar with presentations (all lecturers). In 2015, User-centred sustainability: Why listening to end users matters was also a topic.

During the final seminars, the students' presentations alternated between Vaasa and Turku, as the aim was for all students to experience the fact that they were equally involved, irrespective of whether they participated in Vaasa or Turku. The fourth course version was on a smaller scale and was only held in Vaasa. It had fewer participants and involved fewer lectures and lecturers (four lecture seminars and a presentation seminar) and more individual work by the students. The upcoming fifth course version will also be interdisciplinary, with domestic participants (mainly from social sciences and education) and international master's and exchange students as the target group.

During all of the four course years, most of the students in Vaasa were international master's students, but fewer came from Turku (during the first three years), from where only a handful of students participated. The students' main subjects covered a wide range, from engineering to teacher education, general and adult education and political science. The examination was carried out through course journals and a written essay. In addition, the students wrote journals after each lecture, based on their own views of the themes they had discussed during the lecture. The students could choose which disciplinary angle or sub-area of sustainability on which to base their essay. The lecturers provided the students with the foundations of the current research-based literature from their own disciplines. Even though the students could choose their own topic, the variation in essay topics was wide in all four years. However, before the final grading of student performances, the lecturers discussed the students' activity during all course lectures.

The first pilot course was analysed according to participant evaluations, course diaries, and essays as well as an oral evaluation. The oral evaluation concerning the course structure and themes was very positive [55]. The students claimed that they had learnt new ways to reflect on sustainability and to become aware of its dimensions [55]. In addition, the students found the course content to be current and important, and expressed the view that they regarded sustainability as a key issue now and would do so in the future. The arrangement of subject-specific blocks and joint seminars with essay presentations worked well in relation to the objectives. When it comes to multi-faceted, complex issues such as sustainability, interdisciplinary initiatives make them valuable and enriching. The participants confirmed that they had learnt completely new ways of thinking about issues that they only partially knew before [55]. This was the most positive result of The Complexity of Sustainable Development course.

The participating lecturers found the course to be both instructive and interesting. As noted in the first course analysis [55], it is often difficult to find time for interdisciplinary cooperation with an increasing workload in respective disciplines or subjects, and this makes it a challenge for the lecturers to be motivated. However, it has been possible, with rare exceptions, to arrange the course and lectures within the frame of each lecturer's teaching duty. Since the participants acknowledged in their written course evaluations and in the mutual evaluation discussions that their views on sustainability generally became broader, it was an absolute advantage that the participating students and lecturers represented a range of subjects, and in addition that many of the students came from different parts of the world. The students' and lecturers' varied backgrounds, knowledge and views on the issues aroused interesting discussions in which everyone learned to see sustainability from new perspectives. The problems were mainly of a technical nature. For example, the connection between the campuses did not always work flawlessly, despite the choice of a stable platform (video). 


\subsection{Two More Courses Inspired by the Complexity of Sustainable Development}

As already stated, inspired by The Complexity of Sustainable Development course (Case 1), the authors of this article have had the opportunity to develop two more courses based on the experiences of the interdisciplinary approach. Author 2 developed one course unaccompanied at the University of Hamburg, and Author 1 developed one course with six colleagues at the University of Helsinki.

\subsubsection{Case 1a: The Complexity of Sustainability in Hamburg}

Author 2 arranged a one-lecturer version of The Complexity of Sustainable Development course in Lifelong Learning at the Faculty of Education, University of Hamburg in 2019. He planned the course as a traditional seminar-based course, named The Complexity of Sustainability. The course essentially focused on two full-day seminars, the first on social sustainability connected to urban transformation and the second on popular culture and learning, as well as weekly two-hour lectures/seminars addressing the different pillars and definitions of sustainability, with a focus on social sustainability. Before the full-day seminar on urban transformation, each participating student was tasked to prepare a short presentation about a district and a specific contested place in it, and to discuss the characteristics and specific place-based challenges for local-level social sustainability. Theoretically, the emphasis was on place-based learning through a (structured) development walk [56,57], during which the group visited seven inner-city districts and places with various characteristics (1. St Georg, 2. Hauptbahnhof, Mönckebergstrasse and other main shopping streets in Neustadt, 3. Jungfernstieg/Rathaus/Innen-Alster area, 4. Hafen City, 5. St Pauli, 6. Sternschantze and 7. Rothenbaum). The idea was to present a varied map of the city, where different districts and places face different and various challenges. Accordingly, the students explored districts from the newly built Hafen City to the traditional working-class St Pauli and inner-city shopping districts (in Neustadt).

The seven participating students experienced several urban environments while discussing various place-connected social sustainability challenges. During the course, they experienced connections to the global in the local and the local in the global—that is, how global trends and phenomena connect to local ones, and vice versa.

The other full-day seminar focused on popular culture and included discussions on the prominent role of popular culture in contemporary society and how examples from popular culture may illustrate issues of social and political concern. Before the seminar, each participant was tasked with preparing a short presentation of examples of how popular culture could be used in (social sustainability) education and, subsequently, the students and the lecturer discussed the examples. Popular culture is constantly present today (online, TV, sports, music, films, etc.) and it influences values, norms and behaviours in society. It is therefore important for educators to understand the underlying potential risks, possibilities and challenges connected to popular culture. Popular culture was also discussed as a path to more theoretical learning in districts where traditional school learning may be questioned or even obstructed, for example in the form of hip-hop pedagogy [58]. The seminar also dealt with questions related to the value of using popular cultural examples from TV series, films, music, literature, and so on, for introducing current topics and questions connected to social sustainability, and to influence learning processes in socially deprived areas.

The course language was English, and the participants were both domestic German students and international students. In this course, an interdisciplinary approach was present mainly in lectures on the different pillars of sustainability and various definitions of social sustainability as well as two full-day seminars that focused on very different topics connected with social sustainability. These topics were urban planning and transformation on the one hand, and popular culture and questions related to its use in education on the other. This being the first pilot experience, more systematic analysis of student feedback would have been valuable. However, due to the small number of participants (seven), a more systematic analysis was not considered to be meaningful, and questionnaires before and after the course were not used. Student feedback was still essential and during the final meeting, students were given the task to comment orally on the setup of the course, course content, and especially the 
seminar on urban transformation and experiences of place-based learning in urban environments. All students' comments were positive concerning the setup of the course, and especially the place-based course element. This is valuable student feedback, and information for future courses, even though it was not systematically analysed.

This course strongly focused on the social dimension of sustainability and thus mainly on the complexity of sustainability from a social perspective. Concentration on one dimension, but with introduction and awareness of the different dimensions of sustainability, may be a best-case alternative for one-lecturer courses, while a multi-lecturer version (like the primary course versions held in Vaasa) allow for a wider, more multidimensional and interdisciplinary handling of the very complex issues of sustainable development. This course was arranged as a one-off in Hamburg, as one of the courses arranged by Author 2 during a nine-month guest professorship in 2019.

\subsubsection{Case $1 \mathrm{~b}$ : World Heritage Learning in Helsinki}

Author 1 initiated and led The Suomenlinna Pilot Project, where the disciplines were combined through phenomena [59,60], in contrast to starting from the parts or the whole as Boix Mansilla suggests (see Section 3.2) [54]. This pilot project took place on islands close to Helsinki and was included in the primary teacher education programme conducted by the Faculty of Educational Sciences at the University of Helsinki. Suomenlinna is a fortress situated on eight islands outside Helsinki, and it belongs to UNESCO's world heritage sites. Suomenlinna is protected because of its unique military architecture. Some of the islands are inhibited and has not only an interesting history, but also a specific archipelago nature.

The aim of The Suomenlinna Pilot Project was that the 37 students should experience how to implement phenomenon-based projects and how to develop them in collaboration with various stakeholders [59]. Phenomenon-based learning involves cognitive skills, but the learning process is fundamentally bodily and emotional [61,62], and it is linked to the learning environment [59]. Phenomenon-based learning is often inquiry-based [63]. The learning in this project started from phenomena that touched both social, economic and environmental perspectives. The seven lecturers involved represented several subjects (arts, science, various languages, history, social studies, and philosophy). Of these seven lecturers, at least five mutually functioned as teachers in the project.

In the first pilot project, the seven student groups received phenomena in the form of word pairs, from which they had to plan their inquiry-based learning $[59,60]$. These pairs were children and war, we and they, death and birth, transports and techniques, rats and potatoes, light and shadow, and water and land. Despite starting from completely different word pairs, the students ended up discussing value-related social sustainability issues like poverty, ideology, identity and equality [59].

Research was a part of the course from the very beginning and the lecturers/researchers collected data in the form of video-recorded interactions, students' learning diaries and exit tickets (students' reflective texts). The results show that learning was manifested as a set of emotional and practical experiences, problem solving, reflections and collaboration, and the experiences derived from working together [59]. The conversation analysis sheds light on the process: it shows how the students move from disagreement to consensus when planning a task. At the beginning of the phenomenon-based learning process, the students expressed uncertainty and dissatisfaction. However, during the assignment, the uncertainty gradually disappeared and was replaced by creativity, wonder and cooperation, and the joy of working together [59]. During the process, the students also reflected on what is valuable in life and what pupils should learn at school. An awareness of values also emerged more generally as the students reflected on identity, belonging to a group, and social inequality in the past and today [59]. The learning path went from practical ideas to more and more abstract ones, in which the various disciplines emerged and generated new and more critical views of society in a transdisciplinary way. This process approached what could be called transformative learning, at least in some of the groups. In the first pilot project, sustainability was not an explicit goal, but it was nevertheless an outcome. 
The Suomenlinna Project has hitherto showed that when educators from several disciplinary backgrounds unite, everyone will learn from each other, as Balsamo argues [64]. Balsamo lists virtues of interdisciplinary research as a basis for how to develop a collaboration between representatives from various disciplines. These virtues are also relevant in interdisciplinary or transdisciplinary teaching and learning. They are: (1) intellectual generosity, showing interest in others' ideas, (2) intellectual confidence, belief that everyone can contribute, (3) intellectual humility, knowing that one's knowledge is only partial, (4) intellectual flexibility, ability to change perspectives and imaging other ways to be in the world, (5) intellectual integrity, or responsible participation, a basis for trust. These virtues are all interesting to reflect on and aim for. Like transformative learning, transdisciplinary learning needs to be further tested and developed within sustainability education, since both have great potential in the development of teaching and learning.

From the first pilot project, the planning of The Suomenlinna Project has taken place in collaboration between the seven university lecturers and three members of the Suomenlinna management bodies, and the course will be a collaboration project in the future. The pilot became an eligible five-ECTS course open to all students in the faculty in 2020. Its new name is Phenomenon-Based Learning in Suomenlinna-Sustainability and World Heritage and it will appear in the course programme at the Faculty of Educational Sciences for the 2021 spring semester. This course will be open for all students in the faculty.

\subsection{Case 2: Leadership for Sustainable Global Change}

Case 2 is a course that took place in the Faculty of Behavioral Sciences at the University of Helsinki and had education and adult learning students as its targets. Author 1 initiated and led this course, which had 19 participants. The goal of Leadership for Sustainable Global Change was that after successfully completing the five-ECTS course, the students should be able to identify and discuss current and challenging leadership-related issues within organizations, especially issues of relevance to educational contexts. They should learn to analyse, critically review and problematize governance and management at various social and corporate levels based on scholarly theories.

The course focused on multicultural and worldwide contexts and provided an insight into the basics of sustainable and trustworthy leadership. More specifically, the course dealt with diversity and equality in a global work context, sustainable leadership as a governing instrument in several types of organizations, and trust as a basis for well-functioning leadership. Classical and current leadership theories provided an insight into how societal changes at both international and national levels affect the development of various types of business at the local level. The students became acquainted with real dynamic leadership through case studies.

When starting this course, the lecturer invited all the enrolled students to participate in the planning. Only one student answered this call and turned up to discuss the course with the lecturer before the course programme was finally decided upon. The engagement from this student helped the lecturer to see the students' perspectives better, and it definitely influenced the programme.

The lecturer had educational, leadership and sustainability expertise, but guest lecturers were also invited. Of the 19 students, nine were Swedish speaking and ten were Finnish speaking. The course language was Swedish, but the students could use their mother tongue when speaking or writing, and the lecturer also used English to complement the course, for example, in PowerPoint presentations. The course programme included theoretical lectures, case studies in small groups of about five students and a final seminar with group presentations. The case studies focused on the leadership of an organization or company operating in the Helsinki metropolitan region, but with strong international connections. The students could form groups, choose the working language for the group, and decide which organization they wanted to study. After choosing an organization, they had to contact the leader and arrange meetings themselves. The lecturer only gave examples of possible organizations and, if needed, she helped with advice. 
The students performed their study by reading websites and brochures, and by interviewing and observing leaders of the chosen organizations. Moreover, the students related what they learnt in practice about the chosen organizations to the theoretical lectures, course literature and other theories. The groups and the lecturer met for follow ups during the group investigations, so students could share ideas, give and receive support and advice on suitable items from the literature or practical arrangements.

The organizations the groups had studied were very different; therefore, the outcomes of the investigations were also different. The organizations were both non-governmental organizations (NGOs) and commercial organizations. What the students found out was that what the organizations said they did and what they actually did were not always in agreement. One group also asked employees other than the leader of the organization they studied about how they recognized sustainability, and the students then realized that, often, what was supposedly a strategy on the organization's website was totally unknown to many of the employees.

The course raised many questions and the students managed to respond to them well through their theoretical studies and common discussions. The combination of local and global topics opened the students' eyes to the problematic scale of sustainability concerns. Ethics was another issue that became a core part of the discussions. When the students realized that the theory correlated with practice, and that the leaders used concepts highlighted as important in theories, they were positively affected. They also realized that leadership in an international organization is complex and that there is a big difference between having economic returns and social welfare as goals. This made the students think about what the motivator for doing the work is. The guest lecturer, who was a manager of a large international NGO, could directly answer how she could inspire volunteers to work for social change without receiving a salary.

Due to a specific small group assessment and evaluation procedure (which is not the topic of this text), the course leader had the opportunity to have separate hour-long discussions with all the groups after the students had given their presentations and written their final group essays. This was a successful way of closing the course, and the students were satisfied with giving and receiving feedback orally. Even if a few of the students had completed one or more leadership courses, no one of them were familiar with sustainability leadership before they started the course. They thought it was useful to know about this topic for them as future adult educators, since many of them would aspire to jobs in human resource management or educational leadership tasks. During the course, they had the chance to work independently and take responsibility for a task that, at first, sounded difficult. Gradually, the task became interesting and rewarding and many students said that they learned a lot. To attend a course in and meet students speaking Finland's minority language, Swedish, was also exciting for some of the Finnish-speaking students coming from the inland regions who are therefore not used to Swedish. The students eagerly used Google translate and other digital tools during the lectures to keep up with the content and the discussions.

\section{Concluding Discussion}

The first aim of this article was to define the concept of social sustainability in relation to educational frameworks. Social sustainability relates strongly to the other two dimensions of sustainability, economy and ecology. It is an indistinct and value-laden concept and there are several overlapping definitions. Likewise, social sustainability is difficult to implement in educational settings, because of both its value-laden and context-dependent nature. In short, social sustainability education could be defined as education that promotes a global society that is just, equal, and in which no one is excluded or prevented from participating in social activities and democratic decision-making [21,22,25]. In such a society, everybody is safe [6], everyone can live a decent life in freedom [16], and no one prevent others from participation [25].

The second aim of this article was to discuss what a social sustainability education might contain in various higher educational settings. It is difficult to separate social sustainability education from 
other types of education focusing on sustainability, but all these dimensions build an entity. Not only is the content important, but also the choice of methods.

Higher education in Europe strives to be competitive in the world educational market [65], and sustainability has to match many other, often contradicting, goals. Likewise, higher education institutions involve many stakeholders, from funding agencies, politicians and managers to office staff, lecturers and students. The reason for the slow implementation of sustainability in higher education is due to the competition between divergent goals, the problematic complexity of sustainability and the epistemological differences between the disciplines.

Policy documents about sustainability in higher education stress that sustainability has to include all students, and has to be a part of all subjects and study programs [66]. However, the solving of complicated sustainability problems requires interdisciplinary meta-knowledge [67]. In addition, sustainability calls for innovative and student-centered methods [68], so the students develop an ability to judge, criticize, argue and predict, fight ignorance, and understand various perspectives [69]. Therefore, sustainability education is interactive, participative and problem-oriented [34]. According to many researchers, sustainability education is transformative and interdisciplinary, even transdisciplinary. Learners are encouraged to criticize normative assumptions and to find new perspectives [22,34,43], and to strike a balance between collective and individual interests, long-term and short-term goals [19]. When recognizing the social dimensions in sustainability education, inequality and power issues are emphasized, and such an education focuses cognition on ethics and practice [13,22].

To help the students adapt and change their habits and practices, the learning institutions need to implement sustainability comprehensively, and thus act as sustainability models [35,36]. Until now, sustainability in universities in most countries has more often been implemented at the course level than at a 'whole-university level'. These courses are diverse, realized within several disciplines, and, likewise, their focus varies. Sustainability needs to become a motto or ethos in not only education, but also in the managing of universities and in their interactions with the rest of society. In this process, it is incontestable that sustainability also needs to be present at the course level. Universities are the leading producers of knowledge, and beside education, they have two more main tasks: research and social engagement. Nonetheless, they are conservative institutions with a strong subject orientation, and there is often a lack of interdisciplinary scientific understanding. The researchers include an increasing number of specialists even though sustainability issues are widely connected [70].

When we started to create the first few courses on the topic of interdisciplinary sustainability, this was not a result of the policies at the faculties or departments, but a complete bottom up approach. However, we have welcomed and participated in a gradual change in the faculty policy over the past couple of years and the progress continues.

The two variations of the course, The Complexity of Sustainable Development (Case 1) and Leadership for Sustainable Global Change (Case 2) were both university courses focusing on sustainability, but the course The Complexity of Sustainable Development was much more diverse. Both lecturers and students had diverse backgrounds and their perspectives varied. It is not only the interdisciplinary view that the lecturers created that made this course perspective broad, but also that the students had culturally, socially and economically different experiences in combination with their various disciplinary backgrounds. Since the students could choose the focus on their essays and present the results in shared seminars, they received insight in fields other than their own and simultaneously also in other ways of relating to the sustainability problem. These final seminars were also revelations for the lecturers for the same reason [64]. In this course, the students could alternately encounter parts of (the disciplines) and whole (interdisciplinary) sustainability issues, instead of the two ways Boix Mansilla [54] (see transdisciplinary learning above) and Wolff et al. [13] describe.

In the other main course, Leadership for Sustainable Global Change, the strong point was the authentic learning environment, the bilingual approach, and the students' opportunity to choose organization and create their own investigation. The students were also in a situation in which they 
had to take joint responsibility and collaborate with their groups around a view of the topic that they found most relevant. In this course, all students studied the same main subject, education, and for this reason, the main view of their course topic was education. However, in this course, the students read a diverse section of the literature, also from non-dominant perspectives (and other disciplines) to receive new ideas, the topic was connected to real issues, and they could meet guest lecturers with new thought-provoking views [48].

The common features of course Case 1a at the University of Hamburg (The Complexity of Sustainability) and Case $1 \mathrm{~b}$ at the University of Helsinki (The Suomenlinna Pilot Project) were authentic environments, a connection between local and global perspectives, and the fact that the courses followed an approach in which history met the future in the present. Authentic learning environments build on situated approaches and the idea that learning is best achieved in circumstances that resemble relevant and real-world contexts [71]. In Case 2 the topics for study were real, the students also visited organizations and they talked to actual leaders. The learning was self-directed, emphasizing the students' own activities and interests. In the main feature of Case 1a, place-based learning, students and teachers studied urban environments together, and local students contributed via their backgrounds to local cases, which were then connected to international trends and examples in on-site discussions. In Case $1 b$, the teacher educators acted together, and they cooperated with partners on the learning site. Since mutual teaching is expensive, the teacher educators acted partly on a voluntary basis, because of the own interest in developing university teaching together.

In all four courses we have described, we strived to awaken students' curiosity, as well as their active self-criticism. We also wanted to encourage them to explore the field of sustainability broadly and critically and to continue exploring the topic, especially from views that are relevant to their continuous studies and future duties. In these cases, the learning was more or less interactive, learner-centred, participatory, collaborative and problem oriented [34]). Since the sustainability topic is extremely complex and utterly urgent, the lecturers cannot leave the students to study the topics alone. The lecturers' knowledge, inventiveness, keen engagement and support from the very beginning to the end of the courses are important. The lecturers must be ready to share experience and knowledge with the students, but also to learn with them, and as in Case 1 and Case $1 \mathrm{~b}$, with colleagues from other disciplines and backgrounds.

Through the examples in the cases above, we wanted to emphasize that interdisciplinary, even transdisciplinary approaches, authentic learning environments and a focus on current topics like leadership illuminate the social dimension of sustainability. Sustainability education can have a transformative aim in which transformation has a goal that is not pre-set by the teachers or managers. However, transformative learning is not easy [46,47], but it is still worth trying to develop and improve it. In the Sustainable Leadership for Global Change course, one student was involved in the course planning, but with more targeted involvement, it might be possible to develop courses that best serve students' interests.

Our experience is that interdisciplinary courses with several lecturers require a well-planned information strategy to avoid becoming trapped between the educational structures of individual subjects and education levels. To alternate course responsibility between departments is also worth considering when organizing interdisciplinary multi-year courses. In addition, good infrastructure is important when planning and implementing video or online courses. It creates frustration among the participants and lecturers if the technology does not work, and pilot initiatives should be implemented to account for the failure of the technology. We collected feedback from the students in several ways in the different courses. In Case 1 and Case 1a, the feedback collection was less planned, in Case 2 it was a part of a pilot evaluation process, and in Case $1 \mathrm{~b}$ it was a part of a research project. In the courses with fewer participants (Case 1 in 2018 and Case 1a), it was also easier to have spontaneous discussions with every student. In Case 2, the evaluation discussion took place in small groups of four to five students and the lecturer. When we continued our course development, we became aware of the need to be more systematic and analytical to receive answers that are more reliable. Therefore, the 
experiences from the success of the courses from the students' perspective are not comparable and can only be used as guidelines.

The two new variations of the course The Complexity of Sustainable Development were partly implemented in new ways and, as a result, dependent on other economic, personal and contextual resources. However, our examples also show that sustainability courses can take many shapes and that it is important to create conditions for social sustainability learning at universities. It is an advantage to have many lecturers on the same course, but this is not always possible. Bringing in guest lecturers may then be an option. The student groups are not always diverse, and the environment can be the campus. However, as Cases $1 \mathrm{a}$ and $1 \mathrm{~b}$ show, the courses do not need to be constrained to the campuses, but can also make use of a wider learning environment. If possible, people other than students and lecturers could be involved in the course implementation. This is about making the best of the actual circumstances. It is also a good idea to arrange the courses in collaboration with other universities, even in other parts of the world. Transformation may be the goal, but, if so, it should be the transformation of society, not the purposeful change of the behaviour of others [22]. This implies creating learning conditions that promote critical reflection, awareness of unfairness and other unsustainable circumstances, and the willingness to act. As already stated, transformative learning is always demanding and requires careful planning and application [46].

From the literature and experiences from all four courses, we can list the important elements that facilitate courses focusing on social sustainability. Not all courses can have all of these elements, but the more the better.

\section{Basic elements}

- $\quad$ authentic learning environment;

- good infrastructure and framework;

- economical resources.

\section{Personal elements}

- $\quad$ several lecturers plan and run the course in collaboration;

- the planning and realization of the course should consider collaboration with members outside the university;

- the lecturers and students have a range of backgrounds;

- the students are involved in the planning and/or evaluation of the course.

\section{Educational elements}

- $\quad$ an interdisciplinary or transdisciplinary approach;

- a theoretical and practical view (the students learn the topic in theory, but the topic is also implemented in the methods);

- the methods are student-centred and participatory, but the lecturers' role is crucial;

- there are continuous discussions, formative evaluations and feedback;

- the thematic is most relevant for the students' own lives and may vary between the students;

- transformative learning is an optional aim.

\section{Conclusions}

In summary, we will reflect on our last aim, whether it is possible to achieve a socially sustainable and transformative practice through education. This question is provocative, and based on the literature, the spontaneous answer is that social sustainability is a utopia in educational settings. If we mean that the opposite is that social sustainability becomes a reality in schools and universities, it will be a long time before we reach such a goal. Another discussion could be around whether the entire pursuit of sustainability is a utopia. It probably is, unless it is possible to change human nature [22]. 
The global unsustainability dilemmas are huge and to overcome them in worldwide education might be excessively demanding. However, we need strong utopias as guiding principles to make higher education genuinely transformative. Social sustainability will become a well-versed dimension of sustainability in educational settings only through a total reconstruction of educational practices and management and thus a reorganization of the entire ethical role of educational institutions.

Socially sustainable educational settings are guided by a sustainability leadership principle [40], and not by neoliberal values, and their practice lean on a whole-institution approach [35,36]. However, if sustainability is the aim, a change in procedures must start at both institutional and course levels. The change begins through a collaboration on many levels, involving faculties, institutions, managers, administrators, lecturers, researchers, students, and various stakeholders outside universities. In this process, it is important that people involved in the implementation of sustainability in higher education cooperate and learn from one another. Active education policy reconstruction, global cooperation between universities in diverse contexts and the courage of the lecturers to raise edgy questions about injustice are core elements in this transformation.

Author Contributions: Conceptualization, L.-A.W. and P.E.; project administration, L.-A.W.; methodology, L.-A.W., and P.E.; writing—original draft preparation, L.-A.W. and P.E.; writing—review and editing, L.-A.W. and P.E. All authors have read and agreed to the published version of the manuscript.

Funding: Open access funding provided by the University of Helsinki.

Conflicts of Interest: The authors declare no conflict of interest.

\section{References}

1. UNESCO. Sustainable Development. Available online: https://en.unesco.org/themes/education-sustainabledevelopment/what-is-esd/sd (accessed on 5 October 2018).

2. Roosa, S.A. Handbook of Sustain. Development; Fairmont Press: Lilburn, GA, USA, 2008.

3. IUCN/UNEP/WWF. World Conservation Strategy: Living Resource Conservation for Sustain. Development; IUCN: Gland, Switzerland, 1980.

4. World Commission on Environment and Development. Our Common Future; Oxford University Press: Oxford, UK, 1987.

5. Davidson, M. Social sustainability: A potential for politics? Local Environ. Intern. J. Justice Sustain. 2009, 14, 607-619. [CrossRef]

6. Eizenberg, E.; Jabareen, Y. Social sustainability: A new conceptual framework. Sustainability 2017, 9, 68. [CrossRef]

7. Crutzen, P.J. The "Anthropocene". In Earth System Science in the Anthropocene; Ehlers, E., Krafft, T., Eds.; Springer: Berlin, Germany, 2006; pp. 13-18.

8. Benatar, S.; Upshur, R.; Gill, S. Understanding the relationship between ethics, neoliberalism and power as a step towards improving the health of people and our planet. Anthr. Rev. 2018, 5, 155-176. [CrossRef]

9. UN DESA. World Social Report 2020: Inequality in a Rapidly Changing World. Available online: https:/www.un.org/development/desa/dspd/wp-content/uploads/sites/22/2020/01/World-SocialReport-2020-FullReport.pdf (accessed on 5 January 2020).

10. UN (United Nations). Transforming our World: The 2030 Agenda for Sustainable Development. Available online: https://sustainabledevelopment.un.org/content/documents/21252030\%20Agenda\%20for\% 20Sustainable\%20Development\%20web.pdf (accessed on 5 May 2020).

11. Grindsted, T. Sustainable universities: From declarations on sustainability in higher education to national law. Environ. Econ. 2011, 2, 29-36. [CrossRef]

12. Implementing Rio +20 in the Nordic Higher Education Institutions: A Survey Report. Available online: http://www.sustainabilityexchange.ac.uk/files/rio20_survey_report.pdf (accessed on 15 December 2019).

13. Wolff, L.-A.; Sjöblom, P.; Hofman, M.; Palmberg, I. High performance education fails in sustainability? A reflection on Finnish primary teacher education. Educ. Sci. 2017, 7, 32. [CrossRef]

14. Mochizuki, Y.; Yarime, M. Education for sustainable development and sustainable science: Repurposing higher education and research. In Routledge Handbook of Higher Education for Sustain. Development; Barth, M., Michelsen, G., Rieckmann, M., Thomas, I., Eds.; Routledge: New York, NY, USA, 2016; pp. 11-22. 
15. Dillard, J.; Dujon, V.; King, M.C. Introduction. In Understanding the Social Dimension of Sustainability; Dillard, J.V., Dujon, V., King, M.C., Eds.; Routledge: New York, NY, USA, 2009; pp. 2-12.

16. Konig, J. Social sustainability in a globalizing world: Context, theory and methodology explored. In National Unesco Commission, More or MOST: Proceedings of an Expert Meeting, The Hague, The Netherlands, December 2002; National UNESCO Commission: Amsterdam, The Netherlands, 2002; pp. 63-90.

17. Littig, B.; Grießler, E. Social sustainability: A catchword between political pragmatism and social theory. Intern. J. Sustain. Dev. 2005, 8, 45-77. [CrossRef]

18. Boström, M. A missing pillar? Challenges in theorizing and practicing social sustainability: Introduction to the special issue. Sustain. Sci. Pract. Policy 2012, 8, 3-14. [CrossRef]

19. Roos, J. Practical Wisdom: Making and teaching the governance case for sustainability. J. Clean. Prod. 2015, 140, 117-124. [CrossRef]

20. Boyer, R.H.W.; Peterson, N.; Arora, P.; Caldwell, K. Five approaches to social sustainability and an integrated way forward. Sustainability 2016, 8, 878. [CrossRef]

21. Magis, K.; Shinn, C. Emergent Principles of Social Sustainability. In Understanding the Social Dimension of Sustainability; Dillard, J.V., Dujon, V., King, M.C., Eds.; Routledge: New York, NY, USA, 2009; pp. $15-44$.

22. Wolff, L.-A. Nature and Sustainability: An Educational Study with Rousseau and Foucault; Lambert Academic Publishing: Saarbrücken, Germany, 2011.

23. Bailly, A.; Brun, P.; Lawrence, R.; Rey, M.-C. Towards a Model of Socially Sustainable Urban Development. In Socially Sustainability Cities: Principles and Practices; Bailley, A., Brun, P., Lawrence, R., Rey, M.-C., Eds.; Economica: Geneva, Switzerland, 2000; pp. 129-151.

24. Fox, T.; Pope, M.; Ellis, E.C. Engineering the Anthropocene: Scalable social networks and resilience building in human evolutionary timescales. Anthr. Rev. 2017, 4, 199-215. [CrossRef]

25. Missimer, M.; Robert, K.-H.; Broman, G. A strategic approach to social sustainability. Part 2: A principle-based definition. J. Clean. Prod. 2017, 140, 42-52. [CrossRef]

26. Messer, W.B.; Kecskes, K. Social Capital and Community: University Partnerships. In Understanding the Social Dimension of Sustainability; Dillard, J., Dujon, V., King, M.C., Eds.; Routledge: New York, NY, USA, 2009; pp. 248-263.

27. Bourdieu, P. The Forms of Capital. In Handbook of Theory and Research for the Sociology of Education; Richardson, J.G., Ed.; Greenwood Press: New York, NY, USA, 1986.

28. Bourdieu, P. Distinction: A Social Critique of the Judgment of Taste; Nice, R., Translator; Routledge: London, UK, 1989.

29. Larsen, G.L. An Inquiry into the Theoretical Basis of Sustainability. In Understanding the Social Dimension of Sustainability; Dillard, J., Dujon, V., King, M.C., Eds.; Routledge: New York, NY, USA, 2009; pp. 45-82.

30. Walsh, P.R. Creating a "values" chain for sustainable development in developing nations: Where Maslow meets Porter. Environ. Dev. Sustain. 2011, 13, 789-805. [CrossRef]

31. Marston, S.A.; Jones III, J.P.; Woodward, K. Human geography without scale. Trans. Inst. Br. Geogr. 2005, 30, 416-432. [CrossRef]

32. UNFPA Annual Report: Raising the Potential. Available online: https://www.unfpa.org/sites/default/files/ pub-pdf/UNFPA\%20AR\%202013_LR_FINAL.pdf (accessed on 1 February 2020).

33. Sennett, R. Building and Dwelling: Ethics for the City; Farrar, Straus and Giroux: New York, NY, USA, 2018.

34. Rieckmann, M. Learning to Transform the World: Key Competencies in Education for Sustainable Development. In Issues and Trends in Education for Sustainability Development; Leicht, A., Heiss, A.J., Byun, W.J., Eds.; UNESCO: Paris, UK, 2018; pp. 39-59. Available online: https://unesdoc.unesco.org/ark: /48223/pf0000261445 (accessed on 15 December 2019).

35. Bourn, D. Global learning and the school curriculum. Manag. Educ. 2016, 30, 121-125. [CrossRef]

36. Leal Filho, W.; Raath, S.; Lazzarini, B.; Vargas, V.R.; De Souza, L.; Anholon, R.; Quelhas, O.L.G.; Haddad, R.; Klavins, M.; Orlovic, V.L. The role of transformation in learning and education for sustainability. J. Clean. Prod. 2018, 199, 286-295. [CrossRef]

37. Wolff, L.-A. The Quest for A Route to Sustainable Development in Higher Education. In Towards Sustainability Development in Higher Education: Reflections; Kaivola, T., Rohweder, L., Eds.; Finnish Ministry of Education: Helsinki, Finland, 2007; pp. 58-62.

38. Biesta, G. Should teaching be re(dis)covered? Introduction to a symposium. Stud. Philos. Educ. 2019, 38, 549-553. [CrossRef] 
39. Wolff, L.-A. Det Hållbara Ledarskapets Komplexitet: En Etisk Utmaning För Utbildningssektorn [The complexity of sustainable leadership: An ethical challenge for the educational sector]. In Pedagogiskt Ledarskap: Teori, Forskning Och Skolutveckling_Educational Leadership: Theory, Research and School Development; Uljens, M., Ed.; Åbo Akademi University: Vaasa, Finland, 2015; pp. 77-102.

40. Hallinger, P.; Suriyankietkaew, S. Science mapping of the knowledge base on sustainable leadership, 1990-2018. Sustainability 2018, 10, 4846. [CrossRef]

41. Parkin, S. The Positive Deviant: Sustainability Leadership in A Perverse World; Earthscan: London, UK, 2010.

42. Hargreaves, A.; Fink, D. The seven principles of sustainable leadership. Educ. Leadersh. 2004, 61, 8-13.

43. Seppelin Seppelin, S.; Törn-Laapio, A. Towards Learning Environmental and Social Sustainability: Changing Paradigms of Teaching. In Proceedings of the 6th Higher Education International Conference, Zagreb, Croatia, 27-28 September 2018; Mate Ltd.: Zagreb, Croatia, 2018; pp. 57-63.

44. Mezirow, J. Transformative learning as discourse. J. Trans. Educ. 2003, 1, 58-63. [CrossRef]

45. Mezirow, J. An Overview of Transformative Learning. In Contemporary Theories of Learning: Learning Theorists in their own Words; Illeris, K., Ed.; Routledge: London, UK, 2009; pp. 90-105.

46. Taylor, E.W. Fostering Transformative Learning. In Transformative Learning in Practice: Insights from Community, Workplace and Higher Education; Mezirow, J., Taylor, E.W.A., Eds.; Jossey Bass: San Francisco, CA, USA, 2009; pp. 3-17.

47. Illeris, K. A Comprehensive Understanding of Human Learning. In Contemporary Theories of Learning: Learning Theorists in their own Words; Illeris, K., Ed.; Routledge: London, UK, 2009; pp. 7-20.

48. Burns, H.; Kelley, S.S.; Spalding, H. Teaching sustainability: Recommendations for best pedagogical practices. J. Sustain. Educ. 2019, 19.

49. Biberhofer, P.; Rammel, C. Transdisciplinary learning and teaching as answers to urban sustainability challenges. Intern. J. Sustain. High. Educ. 2017, 18, 63-83. [CrossRef]

50. Donges, J.F.; Winkelmann, R.; Lucht, W.; Cornell, S.E.; Dyke, J.G.; Rockström, J.; Heitzig, J.; Schellnhuber, H.J. Closing the loop: Reconnecting human dynamics to Earth System science. Anthr. Rev. 2017, 4, 151-157. [CrossRef]

51. O’Rourke, M. Comparing Methods for Cross-Disciplinary Research. In The Oxford Handbook of Interdisciplinarity; Frodeman, R.R., Ed.; Oxford University Press: Oxford, UK, 2017; pp. 276-290.

52. Klein, J.T. Typologies of Interdisciplinarity: The Boundary Work of Definition. In The Oxford Handbook of Interdisciplinarity, 2nd ed.; Frodeman, R., Ed.; Oxford University Press: Oxford, UK, 2017; pp. 21-34.

53. Defila, R.; di Giulio, A. Managing Consensus in Inter- and Transdisciplinary Teams: Tasks and Expertise. In The Oxford Handbook of Interdisciplinarity, 2nd ed.; Frodeman, R., Ed.; Oxford University Press: Oxford, UK, 2017; pp. 332-337.

54. Boix Mansilla, V. Interdisciplinary Learning: A Cognitive-Epistemological Foundation. In The Oxford Handbook of Interdisciplinarity, 2nd ed.; Frodeman, R., Ed.; Oxford University Press: Oxford, UK, 2017; pp. 261-275.

55. Ehrström, P.; Wolff, L.-A.; Sjöblom, P. The complexity of sustainability: Ett tvärvetenskapligt kursexperiment [An interdisciplinary course experiment]. Yliopistopedagogiikka 2016, 23, 17-19.

56. Raisio, H.; Ehrström, P. Taking Deliberation to the Streets. Scand. J. Public Adm. 2017, 21, 27-52.

57. Lindell, M.; Ehrström, P. Deliberative walks: Citizen participation in local-level planning processes. Eur. Polit. Sci. 2020, 1-24. [CrossRef]

58. Adjapong, E.; Emdin, C. Rethinking pedagogy in urban spaces: Implementing hip-hop pedagogy in the urban science classroom. J. Urban Learn. Teach. Res. 2015, 11, 66-77.

59. Wolff, L.-A.; Savijärvi, M.; Wallinheimo, K.; Schaffar, B.; Mikander, P.; Slotte, A.; Kaihovirta, H. Arvot ja kulttuuriperintö korostuvat ilmiöiden kautta [Phenomenons highlight values and cultural heritage]. In Ainedidaktisia Tutkimuksia; Kallio, M., Krzywacki, H., Poulter, S., Eds.; Suomen Ainedidaktisen Tutkimusseura: Helsinki, Finland, 2019; pp. 116-143.

60. Wolff, L.-A.; Kaihovirta, H.; Schaffar-Kronqvist, B.; Savijärvi, M.; Wallinheimo, K.; Mikander, P.; Slotte, A. Ilmiöoppiminen yhteistyönä Suomenlinnassa. In Maailmanperintö Ja Kulttuurikasvatus—World Heritage and Cultural Education; Metsärinne, M., Heino, T., Korhonen, R., Esko, M., Eds.; Rauman Normaalikoulu Teacher Training School: Rauma, Finland, 2019; pp. 148-159.

61. Küpers, W. Phenomenology of Learning. In Encyclopedia of the Sciences of Learning; Seel, N.B., Ed.; Springer: Cham, Switzerland, 2012; pp. 2611-2615. 
62. Shapiro, L.; Stolz, S. Embodied cognition and its significance for education. Theory Res. Educ. 2019, 17, 19-39. [CrossRef]

63. Hakkarainen, K.; Lonka, K.; Lipponen, L. Tutkiva Oppiminen: Järki, Tunteet Ja Kulttuuri Oppimisen Sytyttäjinä [Inquiry Based Learning: Reason, Emotions and Culture as Learning Inspirers]; WSOY: Helsinki, Finland, 2004.

64. Balsamo, A. An Ethics of Interdisciplinary Research. In The Oxford Handbook of Interdisciplinarity, 2nd ed.; Frodeman, R., Ed.; Oxford University Press: Oxford, UK, 2017; pp. 255-260.

65. Uljens, M.; Wolff, L.-A.; Frontini, S. Finland: NPM Resistance or Towards European Neo-Welfarism in Education? In New Public Management and the Reform of Education: European Lessons for Policy and Practice; Gunter, H.M., Grimaldi, E., Hall, E.D., Serpieri, R., Eds.; Routledge: London, UK, 2016; pp. 39-42.

66. Christie, B.A.; Miller, K.K.; Cooke, R.; White, J.G. Environmental sustainability in higher education: What do academics think? Environ. Educ. Res. 2015, 21, 655-686. [CrossRef]

67. Dillon, P. A Pedagogy of Connection and Education for Sustainability. In Human Perspectives on Sustainability Future; Rauma, A.-L., Pöllänen, S., Seitamaa-Hakkarinen, P., Eds.; Research Report 99; University of Joensuu, Faculty of Education: Joensuu, Finland, 2006; pp. 261-276.

68. Christie, B.A.; Miller, K.K.; Cooke, R.; White, J.G. Environmental sustainability in higher education: What do academics teach? Environ. Educ. Res. 2013, 19, 385-414. [CrossRef]

69. Weber, L. Universities, Hard and Soft Sciences: All Key Pillars of Global Sustainability. In Global Sustainability and the Responsibilities of Universities; Weber, L.E., Duderstadt, J.J., Eds.; Economica: London, UK, 2012; pp. 3-14.

70. Wijkman, A.; Rockström, J. Bankrupting Nature: Denying our Planetary Boundaries, 2nd ed.; Routledge: New York, NY, USA, 2012.

71. Herrington, A.; Herrington, J. What Is an Authentic Learning Environment. In Authentic Learning Environments in Higher Education; Herrington, T., Herrington, J., Eds.; IGI Global: Hershey, PA, USA, 2006; pp. 1-14.

(C) 2020 by the authors. Licensee MDPI, Basel, Switzerland. This article is an open access article distributed under the terms and conditions of the Creative Commons Attribution (CC BY) license (http://creativecommons.org/licenses/by/4.0/). 